\section{IUMRS General Assembly Meeting Held in Taiwan}

The general assembly of the International Union of Materials Research Societies met on December 20, 1994, in Hsinchu, Taiwan during the IUMRS International Conference on Electronic Materials (ICEM). In addition to current IUMRS business decisions and updates on IUMRS-sponsored events, reports were given by A-MRS (Australia), C-MRS (China), E-MRS (Europe), MRS, MRS-J (Japan), and MRS-Korea. MRS-I (India) was not represented. MRS-Russia joined as a new adhering body.

\section{Russian Membership}

I.V. Gorynin presented the application of Russia for membership in IUMRS, which was unanimously approved. MRSRussia consists of two sections: MRS-St. Petersburg (12 divisions) and SIBASMA (Siberian Association of Materials Research Societies) in Novosibirsk (17 divisions). MRS-St. Petersburg comprises over 300 scientists and engineers who have been working in various Russian regions.

Researchers in MRS-Russia cover various areas such as shipbuilding, aviation, space, transport, power engineering, oil chemistry, medicine, architecture, biology, cultural and historical heritage, catalysis, optoelectronics, nuclear physics, and superconductivity. The Society is involved in all types of traditional metallurgy, surface treatment and coatings, high-power methods of materials treatment, and special techniques. Among various materials, researchers work with high-purity materials; alloys; nitrides, oxides, and silicates; intermetallics; biomaterials; amorphous, microcrystalline, and nanophase materials; high-molecular-weight compounds; and composite materials.

Developing materials research education is a high priority of MRS-Russia, along with information exchange. Russia held the 4th European East-West conference on materials and processes in 1993 in St. Petersburg, assembling over 600 participants from more than 26 countries. MRSRussia has also started a new journal, Problems in Materials Science. MRS-Russia has introduced six research networks comprised of four to five laboratories: special light-weight alloys at Prometey Institute and materials for optoelectronics at IOFFE's Physicotechnical Institute, both in St. Petersburg; materials for nuclear power engineering at the Institute for Non-Organic Materials in Moscow; catalysis at the Institute for Solid States and Mineral Raw Materials Processing in Novosibirsk; the Ceramic Institute for
Solid-State Chemistry in Ekaterinburg (Ural); and the Institute for Superplastics Problems in UFA (Bashkiria).

\section{Official IUMRS Business}

R.C. Ewing (University of New Mexico) was elected as vice president and G.C. Chi (National Central University) was elected as secretary of IUMRS. Vice President Masao Doyama (Nishi-Tokyo University) became president, President Paul Siffert (Centre de Recherches Nucléaires) became immediate past president, and Li-Chung Lee (ITRI, Taiwan) remained as treasurer. Ewing presented an amendment to the bylaws to create the position of General Secretary. The amendment was approved unanimously and R.P.H. Chang currently serves in the position.

Chang presented the treasurer's report which showed a balance of $\$ 44,870$ as of October 31, 1994. The proposed 1995 budget was discussed and approved. The budget proposed $\$ 7,500$ for the 1995 International Conference on Advanced Materials (ICAM), $\$ 5,000$ for operations, $\$ 3,000$ for the design and printing of a brochure to advertise IUMRS, and $\$ 3,900$ for new initiatives in education, technology, and communication.

IUMRS initiated a homepage on the World Wide Web with the access address: http://mrcemis.ms.nwu.edu/.

\section{International Conference on Advanced Materials} IUMRS-ICAM-IV'95

August 27 - September 1, 1995 Cancún, México

This meeting is organized by the Academia Mexicana de Ciencia de Materiales, A.C. AMCM (México) and the Materials Research Society, MRS (USA), with the sponsorship of the International Union of Materials Societies, IUMRS, and of The Minerals, Metals, and Materials Society, TMS (USA).

Abstract deadline: May 31, 1995.

For a list of symposia and information about the conference, contact:

Miguel José Yacamán, Chair

Instituto de Física, UNAM

Apartado Postal 20-364

01000 México, D.F. México

Phone (525) 622-5033

Fax (525) 616-1535.

\section{IUMRS-Sponsored Events}

Chien-Min Wang reported on the IUMRS-International Conference in Asia (ICA) meeting on December 15-16, 1994, held in Hsinchu, Taiwan. The aim of the conference was to provide a forum on structural materials for Asian scientists and engineers. Keynote speakers Hiroshige Suzuki, emeritus professor at Tokyo Institute of Technology, spoke on "Recent Trends and Future Prospect on Materials" and Stephen W. Tsai, Stanford University, addressed "Issues and Challenges of Composite Materials." The conference welcomed 271 attendees from nine countries, and presented 143 papers. Jonq-Min Liu presented information on the IUMRS-ICEM meeting on December 19-21, 1994, held in Hsinchu, Taiwan. The number of attendees totaled 519 from 29 countries. The conference held eight symposia. [See MRS Bulletin, April 1995, page 57 , for more details on both conferences.]

Miguel José Yacamán reviewed the status of the ICAM-IV meeting to be held in Cancún, Mexico, August 27-September 1, 1995. Currently 32 symposia are scheduled [see MRS Bulletin, November 1994, page 56 for more details]. John Bravman reviewed plans for ICEM-96 to be held in conjunction with the 1996 MRS Fall Meeting in Boston. Ten to 12 symposia on electronic materials are to be designated as the ICEM meeting with MRS. Four meeting chairs, including Karen Max from Belgium and Werner Lutze from the United States, are to organize the combined MRS and ICEM meeting.

\section{Adhering Bodies Activities}

Bravman reported on the 1994 MRS Spring and Fall Meetings in which attendance was approximately 2,800 and 4,500 , respectively. He reported a continued, steady growth in subscriptions for the Journal of Materials Research.

P.A. Glasow reported on the activities of E-MRS, reiterating the point that the October 1993 meeting was moved from Strasbourg to St. Petersburg, cosponsored by f.e.m.s., MatTech, and Prometey. The Spring Conference (May 24-27, 1994) was held in Strasbourg, featuring eight symposia. The Spring Conference in 1995 is to be held May 22-26 in Strasbourg, featuring 14 symposia.

Ruisheng Zhang presented activities of MRS-C. The Society held its annual meeting in Beijing on November 12-15, 1994. Over 1,500 papers were received. The conference welcomed approximately 1,500 attendees, marking this meeting as 
the largest held in materials science in China. Proceedings in 13 volumes are currently being edited. Among the speakers were Masao Doyama (current president of IUMRS); Min-Che Chon, 1994 president of MRS-Korea; Janos H. Fendler from Syracuse University in the United States; and Ryoichi Yamamoto from the University of Tokyo. C-MRS and MRS-J plan to jointly hold a Sino-Japan Environment-Conscious Materials Symposium on September 10-16, 1995, in Xi 'An. Zhang also announced the Society's publication of a Materials Comprehensive Dictionary, compiling 8,000 terms which amounted to 3.4 million words in total; 8,000 copies had been printed.

You Song Kim reported from MRSKorea. The number of members increased by 100 from 1993 to 1994 . The Society's publication, Korean Journal of Materials Research, runs eight issues (approximately 118 papers) a year with a circulation of 7,200 . In regards to conferences, Kim reported over 120 papers and seven invit- ed talks presented at the 1994 Spring Meeting held at Pusan National University in Pusan, Korea. About 300 scientists attended. The topics covered included electronic and magnetic materials, polymers, alloys, and composites. About 350 scientists attended the 1994 Fall Meeting held at Seoul National University in Seoul, in which over 150 papers and five invited talks were presented. Kim announced that Jin-Tae Song was elected as president of MRS-Korea for the 1995-1996 term.

Doyama presented the activities of MRS-J. The 1994 Summer MRS-J Symposium was held on July 11-12 at Kanagawa Science Park Hall in Kawasaki City, with about 100 attendees. The conference brought together metallurgists, semiconductor scientists, ceramists, and organic and polymer scientists. Fifteen lectures and 50 posters were presented. The next meeting was scheduled for December 8-9, 1994, at the same location. Two plenary speakers were scheduled: Saburo Nagakura to lecture on "Structural and Func- tional Relationships between Molecules and Molecular Systems" and Makoto Kikuchi to speak on "Some Lessons from the History of Semiconductor Research." Former MRS-J president S. Sōmiya presented R.M. Spriggs, J.F. McMahon Professor of Ceramics at Alfred University (USA), with an honorary member certificate for MRS-J on October 21, 1994.

Gang Li reported from A-MRS, which sponsored one conference in 1993 and published its first conference proceedings. Li said that A-MRS was scheduled to host the IXth International Conference on Ion Beam Modification of Materials in February 1995, expecting approximately 600 attendees, mostly from outside Australia. Two workshop proceedings are to be published by A-MRS.

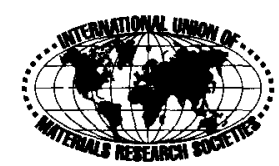

\section{MRS and SAMPE Together!}

The 27th Int'I SAMPE Technical Conference will take place at the Hyatt Regency in Albuquerque, New Mexico October 9-12, 1995. MRS as co-sponsor of this meeting will be organizing several technical sessions.

Session Topics Include:

Materials: Composite - Flat Panel Display $\cdot$ Reconstruction/Conservation of Museum Artifacts - Printed Circuit Substrate -Smart Processing • Nanocomposites. Manufacturing: Advanced Processes $•$ Environmentally Conscious •RTM. Composites: Anaylsis • Sunrise Car and Pickup. Advanced Electronics Applications • Smart Card Technology • Surface Preparations for Adhesion

\section{Misit to the Occasion!}

This meeting is taking place during the annual Albuquerque Int'l Balloon Fiesta. On Wednesday morning, there will be no sessions in order that attendees can observe the balloon ascensions. SAMPE has arranged for bus transportation to the balloon field.

Because of the tremendous crowds during the Fiesta, hotel, airline, and car rentals will be at a premium. Make your reservations early to avoid future difficulties.

For further information on the Conference, hotel, airline, and car rental information, contact SAMPE at 818/331-0616 ext. 603.

\section{MIRS 1995 Fall Meeting Update}

You are welcome to submit your abstract via e-mail to F95abst@mrs.org. However, subscripts, superscripts, or formulas may not be received accurately.

$$
\begin{gathered}
\text { You are welcome to mail your abstract } \\
\text { by June 23, } 1995 \text { to: } \\
\text { Attention: Abstract Enclosed } \\
\text { Materials Research Society } \\
9800 \text { McKnight Road } \\
\text { Pittsburgh, PA 15237-6006 } \\
\text { or fax (412) 367-4373 }
\end{gathered}
$$

The 1995 Fall Meeting Call for Papers is in this issue of MRS Bulletin and on the MRS Homepage on the World Wide Web: http://dns.mrs.org/

If you would like any other information regarding the Materials Research Society, visit us on the Web: http://dns.mrs.org/ 